\title{
Könyvszemle
}

SIPOS JÚLIA GONDOZÁSÁBAN

\section{SZÍNHÁZI NEVELÉSI ÉS SZÍNHÁZPEDAGÓGIAI KÉZIKÖNYV}

A színház és a pedagógia metszéspontjában található terület, amelyet az elmúlt huszonöt évben színházi nevelésnek, újabban színház-pedagógiának is hívunk, töretlenül terjed, növekszik, fejlődik, virágzik Magyarországon.

A kiadvány első felében három hiánypótló tanulmányt közlünk. Novák Géza Máté Alkalmazott színház Magyarországon címü, átfogó írásából megismerhetjük a területünket „körülölelő” alkalmazott színház számos hazai müfaját és gyakorlatát. Az írás sorra veszi a színház önismereti és terápiás, szociális és közösségi, valamint for-profit és szervezetfejlesztési alkalmazásait. (Erről részletesebben a jelen számban, Novák et al. 843-850. oldal.) Golden Dániel Szinház és nevelés Magyarországon címü tanulmánya már szűkebb területünkre fókuszál. Az írás a színházi nevelés elmúlt évtizedeinek kritikai rekonstrukciójára vállalkozik, különösen fókuszban tartva a terminológia, a minősítés és a stratégia kérdéseit. Bethlenfalvy Ádám Szinházi nevelési programok - nemzetközi kitekintés címü tanulmánya áttekinti a terület nemzetközi gyakorlatát. A szerző megerősíti azt, amit eddig csak sejtettünk: a hazai színházi nevelés és színház-pedagógia mind sokszínüségét, mind elterjedtségét, mind minőségét tekintve nemzetközi viszonylatban is az élvonalban van.

A kiadvány második felében közel féléves egyeztetési folyamat eredményeképpen létrejött javaslatcsomagot talál az olvasó. Három munkacsoport dolgozott párhuzamosan három javaslaton a színházi nevelési/színház-pedagógiai programok terminológiája, minösitése, valamint az ilyen programokat létrehozó szervezetek közös stratégiája kapcsán. Az egyeztetési folyamat alulról jövő kezdeményezés volt, az elmúlt években számos szakmai fórumon megfogalmazott kérdésekre próbált reagálni. Arra tettünk kísérletet, hogy a területünket évek óta foglalkoztató kérdésekre önszerveződéssel és széles körü szakmai vitával keressünk közös válaszokat.

A 2017-es évben megvalósuló egyeztetési folyamat eredményeit: a mintegy kilencven szakember hozzászólásai alapján kialakult végleges javaslatokat a kötet második felében tettük közzé. A terminológia területén javaslat született a színházi nevelési/színház-pedagógiai programok müfajainak pontos elnevezéseire és azok definíciójára. Az ilyen programok minősítése kapcsán javaslat született egy 
olyan komplex, visszajelzés-alapú rendszerre, melyben szakemberek, pedagógusok és résztvevők egységes szempontok alapján tudják értékelni a programokat. A stratégiában a szakmaiság, a hozzáférhetőség, a képzés-kutatás és a források fejlesztési területén születtek konkrét vállalások, feladatok és ajánlások.

A záró tanulmány az előttünk álló feladatok mellett áttekinti a szakmát jelenleg leginkább foglalkoztató kérdéseket. A színházi nevelés és színház-pedagógia viszonyát leíró, egymással versengő modellekről is sok vita zajlik. Az elmúlt huszonöt évben volt, aki amellett érvelt, hogy a színházi nevelés olyan gyüjtőfogalom, amelynek része a szinház-pedagógia is; mások épp az ellenkezőjét állították. Sokak szerint egymás mellett létező, esetleg kissé átfedő területekről van szó, és legalább ötféle javaslat van arra, hogyan lehetne a két területet szétválasztani. Továbbá van, aki amellett érvel, hogy a két fogalom szinonima.

A másik fontos kérdés, hogy területünk önálló diszciplina-e, vagy lehet-e az valamikor. Tisztán látszik, hogy a színházi nevelés és színház-pedagógia területére legalább nyolc jól elkülöníthető diszciplína - például a színháztudomány, a neveléstudomány, a pszichológia - van hatással, de hogy mindezek metszéspontjában egyszer létrejön-e önálló diszciplína, például a művelői által egységesen használt önálló terminológiával, ma még nehezen megjósolható.

(Cziboly Ádám szerkesztö: Szinházi nevelési és színházpedagógiai kézikönyv. Budapest: InSite Drama, 2017)

Cziboly Ádám PhD, kulturális menedzser, drámatanár, InSite Drama 


\section{TÖRÉSEINK ÉS ÁTTÖRÉSEINK A ZENEI NEVELÉS FOLYAMATÁBAN}

Az elmúlt év végén a lengyelországi Słupsk egyeteme, Music Education in Continuity and Breakthrough: Historical Prospects and Current References in a European Context címmel, zenepedagógiával foglalkozó kutatók angol nyelvü tanulmányait adta ki könyv formájában. A kötet első része a „visegrádi” országokból való szerzők munkáit tartalmazza, akiktől a szerkesztők (nagy vonalakban) az alábbi témakörökben kértek írásokat:

- Zenetanítás a reformpedagógiai irányzatok, a zenetanulási lehetőségek és az élethosszig tartó tanulás kontextusában.

- A zenetanítás szociokulturális feltételei: történeti megközelítések és jelenkori lehetőségek.

- Nemzetközi párbeszéd a zenepedagógiában: hasonlóságok, különbözőségek.

- Tradíció és innováció az általános zenei nevelésben.

- Kortárs irányzatok a hatékony előadás és a reflektív befogadás együttes megvalósulására irányuló zenepedagógiában.

- A zenei nevelés mint állandó eszköz a humanista szellem és a kulturális örökség folyamatos továbbadására, megőrzésére.

A második rész nyugat-európai (német, valamint luxemburgi) kutatók tanulmányait tartalmazza a „tudatos” zeneedukáció fejlődéséről, illetve hatásáról az amatőr zenei mozgalmakra. A két, látszólag különálló gondolatkör legfőbb öszszekötője egy jelentős, sokoldalú és érdekes nevelő személyiség: Leo Kestenberg.

Kestenberg, aki a monarchiabeli Rózsahegy/Rosenberg/Ružomberok 1882-es szülötte, életművét Berlinben kezdte építeni, ám később Prágába, majd Tel Avivba kellett menekülnie, ahol 1962-ben hunyt el. Kényszerü törésekkel tüzdelt életútja azonban áttörést jelentett a nemzetközi zenei nevelésben. (Számunkra, többek között, azért vált fontossá, mert az 1953-ban általa alapított International Society for Music Education [ISME] néhány év múltán nagy szerepet kapott a Kodály-pedagógia megismertetésében.) Ö lett a tanulmánysorozatot megalapozó 2014-es, szintén a lengyel városban rendezett konferencia „kulcsfigurája” is, mivel munkássága és sorsa egyaránt azt üzeni az utókornak, hogy a jól felépített zenei edukáció egyúttal a párbeszédre, valamint az értékek kölcsönös elfogadására, végső soron az egymás mellett élés békéjére nevel.

Az említett rendezvény amúgy szinte megtestesítette mindazt, aminek a Weimari Köztársaság meghatározó zenepedagógusa a szimbóluma lett. A Pomeránia tartományban lévő Słupsk, egykori Hanza-város - amely a gyakran változó fenn- 
hatóságok okán, német, svéd, sőt (egy önálló identitástudattal rendelkező helybéli népcsoport jóvoltából) kasub megnevezéssel is illethetö - mozgalmas történelme során mindig nyitottságáról, toleranciájáról volt híres, örömmel fogadta a különböző országokból, sokszor meglehetősen eltérő mondanivalóval érkező előadókat. (Ezt erősítette a lengyel, szlovák, cseh és magyar zenész-oktatók nyitóhangversenye a helyszínül szolgáló reneszánsz kastélyban, és, ellenkező végletként, egy ukrán előadóval Skype-on keresztül folytatott „plenáris beszélgetés”, aki a lakóhelyét épp érintő háborús cselekmények miatt nem tudott elutazni a konferenciára.)

E befogadó szellem jegyében, az írások között található a „Kestenberg-reform” szükségességét indítványozó terv, valamint oktatási filozófiájának eddig háttérbe szorult elemeit bemutató kutatás, illetőleg Kestenberg és munkatársa, a Słupsk városából származó Eberhard Preußner tevékenységének lengyel- és csehországi hatásait elemző tanulmány. De ugyanígy szó esik az európai „zenetanár-identitás" sokféleségéből fakadó problémákról, a szlovák és a magyar zeneoktatás kihívásairól a 20. század második felének társadalmi folyamatai tükrében, vagy Kestenberg „,szovjet zóna”-beli recepciójáról a II. világháborút követő években.

Örvendetes, hogy az alkotók és az előadók egyebek közt, Varsó, Gdańsk, Brno, Harkov, Eperjes, Trencsén, Budapest, Szeged, Freiburg, Würzburg és Luxemburg egyetemeit képviselték: jó ajánlás lehet és lehetett ez a további, hasonló indíttatású magyarországi eseményekhez, így a novemberben megrendezett Kodály-Kestenberg konferenciához. ${ }^{1}$

(Chaciński Jarosław - Brusniak Friedhelm szerkesztök: Music Education in Continuity and Breakthrough: Historical Prospects and Current References in a European Context. Stupsk: Wydawnictwo Naukowe Akademii Pomorskiej, 2017, 286 o.)

Bodnár Gábor DLA, tanszékvezető egyetemi docens, Eötvös Loránd Tudományegyetem Bölcsészettudományi Kar Zenei Tanszék

URL1: https://kodalykestenbergconference.wordpress.com/ (2017. 12. 13.)

\footnotetext{
${ }^{1}$ Kodály-Kestenberg Conference. Motto: 'Music Education in the Focus of Historical Concepts and New Horizons' (URL1).
} 


\section{MÉG MINDIG A NÉMETEK KÍVÁNCSIAK RÁNK}

Még mindig a németek kíváncsiak ránk. Azért kezdem ezzel a kijelentő mondattal a könyv ismertetését, mert napjainkban, még a humán, sőt, ezen belül még a történeti tudományokban is elterjedt az értelmetlen anglománia. Túl azon, hogy az egynyelvüség egyben a gondolkodás egysíkúságát is jelenti, egyértelmüen vicces, ha egy német kulturális terület történész kutatói egymással angolul beszélgetve (pontosabban: kommunikálva) okosakat mondanak azokról a német nyelvü történeti forrásokról, amelyeket persze nem olvastak (a terület történeti forrásainak jelentős hányada ugyanis ezen a nyelven keletezett, és soha nem fordították sem latinra, sem a nemzeti nyelvekre). A tény, hogy a németek és még a német történészek is, jobban tudják, hol fekszik Közép-Európa - még ha kényelemböl, politikai érdekből vagy egyszerüen a legújabb kori agymosás következtében a német értelmiség jelentős része el is feledte-, mint mondjuk a hollandok, franciák és legföképpen az angolok, különösen fontossá teszi ezt a könyvet.

Persze, nem véletlen, hogy éppen most jelent meg. Nagyon is aktuális. Nem azért, mert ezzel párhuzamosan megjelent a München/Regensburgi Magyar Történeti Intézet gondozásában egy másik kötet is, amely politikailag is aktualizál a kérdés kapcsán - kik a magyarok? mit akarnak? hogyan látják magukat? mit ugrálnak ezek? -, hanem mert újra és újra alá kell húzni a tényt: nincsen egyféle nemzeti történelem. Szükségünk van a külső szemre, és a külső szemek ítélete, a megfogalmazás elött, igényli a mi látásmódunk megismerését, vagyis a belső szemet (Ungarn, Deutschland, Europa. Einblicke in ein schwieriges Verhältnis. Lengyel et al., 2017). De ne legyünk naivak sem. Azok az értelmiségiek, akik évszázadok óta, de mindenképpen Gragger Róbert (a „hungarológia - magyarságtudomány" fogalom első definiálója) óta tudatosan és programszerüen dolgoznak azon, hogy egymás megismerése szükségességének fontosságát hangsúlyozva alapot teremtsenek arra, hogy a történelmi időkben kialakított klisék, stigmák változzanak, soha nem találtak tényleges meghallgatásra. Soha nem kaptak tényleges mozgásteret. A gazdasági érdek önző, csak úgy tudja az egyre nagyobb hasznát biztosítani (és a „ki a gazdagabb” óvódás versenyben egy hellyel előbbre jutni), ha a népek nem békésen élnek egymás mellett. A mostani Európai Unió is csak Közös Piac. Lehet, hogy volt, van olyan komoly politikus, még az is lehet, hogy a gazdasági élet szereplöi közt is vannak olyanok, akik ennél többet szeretnének, egy Európai Szövetkezett Államokat, de ettől még nagyon messze vagyunk. Azok az értelmiségiek, akik valóban bele tudnak helyezkedni egy másik nép, egy másik kulturális csoport szempontrendszerébe, a mostani EU-ban nem találnak helyet maguknak. Hacsak nem olyan konfliktus alakul ki, amelynek 
okaira már a szabad verseny „demokrata” lovagjai is kíváncsiak. Úgy tünik, a mai Németországban újra vannak olyanok, akik meg akarják tudni, hogy milyen emberek is élnek ott, ahol befektetni akarnak, akikkel szövetséget kívánnak kötni. És jó tudni, hogy nem csak olyanokhoz fordulnak, akik valamit hallottak az illető területről, ne adj Isten, olyanokhoz, akiknek csupán ismerőseik vannak ott, és csupán az ő ítéletük alapján gondolnak valamit mondani a megrendelőnek. A jelenkori német történetírásban van egy új komparatista hullám, sorra jelennek meg az olyan elemzések a közép-európai országok történetéről, amelyek szerzői nem feledték el, hogy ez a terület megérthető a német befolyás történetének kutatásával. Ugyanakkor megérthető, ha az itt élő egyes népek történetében, müvelődéstörténetében a német eszmék recepcióját kutatják. Közben megismerik az itt élők mentalitását, és, szerencsés esetben - mint amilyen Gabriella Schuberté is -, arról is közeli, életszerü képet nyernek, hogy az itt lakók egymást miként szemlélik. Gabriella Schubert magyarságképe ugyanis nem független attól, hogy ő szlavista is, nem csupán hungarológus, illetve történész, a Szerb és a Magyar Tudományos Akadémia külső tagja. Számos tanulmányban foglalkozott a közép-európai és balkáni népek nyelvével, néprajzával, müvelődéstörténetével és persze politikatörténetével is. Nem beszéltem vele, de gondolom, az elmúlt évek politikai történései okán is megszólítva érezte magát arra, hogy a magyarokkal (Budapesten született) kapcsolatos életmüve megkoronázásaként összefoglalja a német történészeknek azt, amit ő a magyar önképről megtudott. Könyve persze jól olvasható lenne bármely átlag német értelmiséginek, akár egy, csupán érettségizett polgárnak is, de napjainkban a véleményformálás olyan mértékig kikerült az egyes ember személyes döntése köréböl - Németországban különösen igaz, hogy a sajtószabadság elhozta a véleményrabságot (a ló másik oldala) -, hogy csekély az esélye annak, hogy néhány történészen túl más is olvassa. Pedig érdemes. A magyaroknak is érdemes, mert tükröt tart elénk is.

A könyv valóban összefoglaló, németes logikával felépített kézkönyv. Hihetetlen nehéz lehetett megírni, hiszen mindenütt téziseket fogalmaz meg, majd annak gyengeségeit és erősségeit is körbejárja úgy, hogy minden érvhez szakirodalmi elődöt, vagyis egy azt megfogalmazó szaktekintélyt állít. A könyv irodalomjegyzéke egy jól válogatott szakirodalmi bibliográfiája a kérdésnek. Olyan, amely öszszehozza - csak egy példaként - a Kristó Gyula-szerű akadémikus történészt, a közíró, gondolkodó Konrád Györggyel (akik talán [nem állítom] soha nem olvasták egymást). Az egyes fejezetekhez persze mindig lehet találni újabb és újabb, a szerző által nem idézett tanulmányt vagy könyvet, de teljesen felesleges. A kép koherens, Gabriella Schubert magyarságképe. Egy hosszú, évtizedes tudományos kutatással megalapozott kép. Vitatható is természetesen. Részleteiben biztosan, de egészében már nehezebben. Német nyelven azonban olyan magyar történeti összefoglalás, amely a magyarok történelmének vázát úgy tanítja a németül olvasóknak, hogy leginkább olyan toposzokat, közismert neveket - irodalmunk, 
zenei életünk stb., napjaink - mutat be, tesz identitástörténeti elemzése alapjául, amelyeket, akiket a német átlag értelmiségi is ismerhet.

Nagyon fontosnak látom, hogy egy német környezetben dolgozó - a szerző 1971-től Berlinben alkotott, 1995-től a Jénai Friedrich Schiller Egyetem szlavisztika professzora volt 2008-as nyugdíjba vonulásáig - külön, a bevezető fejezetekben jelentős figyelmet szentel annak a kérdésnek, hogy a magyarok hogyan látják, mely részén élnek ők Európának. Az „Osteuropa”, „Mitteleuropa”, „Ostmitteeuropa”, „Südosteuropa”, „Südosteuropa-Balkan”, vagy éppen a „Zwischeneuropa" csak látszólag olyan kérdés, amely végül is, ahogy nézzükel elintézhetö. Akik gondolkodnak vagy gondolkodtak a kérdésről, komolyan teszik ezt a magyar oldalon és a német történeti mühelyekben is. Főképp azt, hogy azon a területen, amelyet éppen megnevezünk, kik élnek még rajtunk kívül. No és, hogy milyen szempontok szerint tartjuk ezeket a népeket éppen ott élőknek. Egyetlen párhuzam a mostani könyvvel: Joachim Bahlcke Közép-Európát „Kelet-Közép-Európának" tartja. Méghozzá úgy, hogy abba beletartoznak a bolgárok, a románok, ukránok, szerbek, bosnyákok, horvátok, magyarok, szlovákok, lengyelek, litvánok és még más kisebb népek. A finnek, az észtek, a lettek nem, és persze az osztrákok sem. A 2013-ban megjelent, egyes tanulmányaiban kiváló, általa szerkesztett kötet a vallási emlékezethelyekről (Religiöse Erinnerungsorte in Ostmitteleuropa. Konstitution und Konkurrenz im nationen- und epochenübergreifenden Zugriff, Bahlcke et al., 2013) összehoz mindenféle vallású emlékezethelyet, de mondjuk Mariazell nincsen benne (ugye az Stájerország és Alsó-Ausztria határán fekszik). A kötetnek az az üzenete, hogy no lám, ez az „Ostblokk”, ezek ott együvé tartoznak. Aztán valahogy ez a kép nem stimmelt a Luther-hatás „Ostmitteleuropában” kérdésre, így az egyszerüen ,a keleti Európa részre” változik (Der Luthereffekt im östlichen Europa. Geschichte - Kultur - Erinnerung, Bahlcke et al., 2017) tegyük hozzá rögtön, sem az észtek, sem a magyarok nem a „keleti” részén élnek Európának, vagy ha igen, akkor mondjuk ki: Európa határa a nyugati kereszténység határánál van. Ezt kimondani egy németnek pedig manapság tilos (és tegyük hozzá, hogy így egyszerüen nem is igaz, de kimondani ettől még tilos). Pedig csak arra kellene figyelni, hogy a nyugati szellemi áramlatok befogadástörténete pontosan ugyanaz a finnek, az észtek és a lettek közt, mint a litvánok, lengyelek, magyarok közt. De egészen más a szerbek, a románok, vagy éppen bolgárok közt. Ugyanez vonatkozik az intézményi rendszer alakulására is.

Gabriella Schubert pontosan érzékeli, és tudja tehát, hogy a „hol élünk mi?” egyáltalán nem közömbös az identitásunk szempontjából. Nekem Schubert professzor könyvének ebben a részében nagyon hiányzik Pándi Lajos neve (általában is, nem szokás ôt emlegetni). A szegedi József Attila Tudományegyetem Történettudományi Intézetében hangsúlyozódott a „Köztes-Európa” (Zwischeneuropa) elképzelés, és ennek szép eredménye egy Köztes-Európa-térképgyüjtemény, egy kronológia, és egy helynévlexikon, sőt, egy ilyen címü folyóirat is indult (Pándi, 
Köztes-Európa 1763-1993. Térképgyüjtemény, 1997; Bencsik, Helységnévváltozások a Köztes-Európában 1753-1995, 1997; Pándi, Köztes-Európa 1756-1997. Kronológia, 1999). A szerző is ismeri a fogalmat, említi is, de magam azt hiszem, mi magyarok, erröl többet gondolkodunk, mint ahogy az a könyvben hangsúlyt nyer.

Gabriella Schubert könyve, ahogy mondtam, aktuális. De nem aktualizál. Nem eléggé. Ugyan van olyan fejezete, amely a mai magyarok magyarságképéről állít téziseket (Wo positioniert sich Ungarn Heute?), de a 2010 utáni Magyarországról mégis visszaköszönnek a német sajtó kliséi. Itt a szerző szakít a történeti látásmódjával. Nem vádol, nem ítél, csak éppen kihagy. Kihagyja, hogy Magyarországon ma nagyon sokan gondolják, hogy a kettős vagy sokoldalú mérce az egyes népek megítélésében a magyarok számára mindig kedvezőtlenül fordul. Függetlenül attól, hogy - és ezt a könyvből is megtanulhatjuk - a magyaroknak a legtöbb bajt a magyarok okozták, és nem a gonosz külföldiek, az 1990-es éveknek a magyarok többsége hittel, lelkesedéssel, naivitással és vaksággal vágott neki. Ezzel „szövetségeseink” éltek és visszaéltek. Az I. világháborútól 1996-ig (a versailles-i békeszerződés érvényessége) büntetésben élő, történelmi és makroökonómiai szempontból lerongyolódott országnak csak annyit tudtak ajánlani, hogy: szabad verseny, a tőke szabad mozgása, a vállalkozás szabadságának mindenek felettisége. Minden, ami Európára utal, azt felejtse el a magyar, mert már elkéstek a nemzetépítéssel, az elavult dolog, ma már csak globálisan lehet gondolkodni (mert ez azoknak az érdeke, akik nyertek az első, a második világháborún, az iraki háborún, és nyerni akarnak az ukrán konfliktuson, és valamennyin, amelyet ők maguk generáltak). A kulturális nemzet fogalma pedig nem létezik, vagyis aki kulturális egységet akar, az nacionalista, sőt akár soviniszta.

Ahogy Gabriella Schubert jól látja, és kevéssé jól mutatja be, mi is volt az alapvető gondja a magyaroknak a 18. századi „európaizálási” törekvésekkel, pontosan látja, hogy a magyar a legbefogadóbb népek egyike, ezeket a tulajdonságokat, ezeket a szempontokat az 1990 utáni helyzet bemutatásában elfeledni látszik. Nemcsak a középkorban volt „Gastland” Magyarország, és nyitottak a magyarok maguk, hanem napjainkig. A szimbólumok súlyát meg kell ismerniük ma a magyaroknak, és jó, ha a németek is tudják, a magyarok ezt hogyan értik. Mert nem az a megoldás, hogy betiltjuk a történelmi szimbólumokat, a történelmet vagy éppen a hagyományainkat, mert az - egy nem pontosan definiált szempontrendszer alapján -, állítólag, valakiket sért. Szembenézni a történelemmel, önmagunkkal lehet flagelláns módjára is, különösen, ha van olyan érdek, hogy korbácsoljuk csak magunkat (a németek ezt a kérdést a legnagyobb mélységekig ismerik). De lehet úgy is szembenézni, hogy megismerjük egymást, a kölcsönösen, egymásról kialakított képet. Igen, ez nehéz dolog, sokáig tart, az (egyébként nem létező) „fejlődés" nem enged erre időt. De pontosan az olyan okos könyvek, mint Gabriella Schubertté segítenek ebben. Talán az is, hogy a könyv tanulságait nem engedjük 
egyoldalúan interpretálni. Mert lehet ezt a könyvet is úgy olvasni, hogy a végső következtetés az, hogy a magyarok csak hiszik azt, hogy európai népek részévé váltak, megmaradtak csökönyös kívülállóknak. De lehet úgy is, és bízzunk, az ilyen olvasók lesznek többen, hogy igen, ez egy külön történet, ismerjük meg, és ha velük kapcsolatba kerülünk, tudjuk, mire érzékenyek, mi az, amit nem szeretnének, miben lehet rájuk számítani.

(Gabriella Schubert: Was ist ein Ungar? Selbstverortung im Wandel der Zeiten. Wiesbaden: Harrassowitz, 2017, 319 p.)

Monok István

művelődéstörténész

a Magyar Tudományos Akadémia Könyvtár és Információs Központ főigazgatója

\section{IRODALOM}

Bahlcke, J. - Rohdewald, S. - Wünsch, Th. (Hrsg.) (2013): Religiöse Erinnerungsorte in Ostmitteleuropa.Konstitution und Konkurrenz im nationen- und epochenübergreifenden Zugriff. Berlin: De Gruyter

Bahlcke, J. - Störtkuhl, B. - Weber, M. (Hrsg.) (2017): Der Luthereffekt im östlichen Europa. Geschichte - Kultur - Erinnerung. (Schriften des Bundesinstituts für Kultur und Geschichte der Deutschen im östlichen Europa, Bd. 64) Berlin: De Gruyter

Bencsik P. (1997): Helységnévváltozások a Köztes-Európában 1753-1995. Budapest: Teleki László Alapítvány

Lengyel Zs. K. - Göllner, R. Th. - Aschauer, W. (Hrsg.) (2017): Ungarn, Deutschland, Europa. Einblicke in ein schwieriges Verhältnis. (Studia Hungarica, Bd. 53. Ungarisches Institut, Regensburg) Regensburg: Verlag Friedrich Pustet

Pándi L. (összeáll.) (1997): Köztes-Európa 1763-1993. Térképgyüjtemény. Budapest: Osiris Kiadó

Pándi L. (összeáll.) (1999): Köztes-Európa 1756-1997. Kronológia. Budapest: Teleki László Alapítvány 